\section{Het onderzoek van het onderzoek : het archief van de Procureur des Konings te Brussel}

Rik De Coninck, departement Archief $A M S A B$

Tussen de Belgische archieven die door de nazi's meegenomen zijn en in 1992 ontdekt werden in de zogenaamde Osoby- of Speciale Archieven in Moskou (momenteel her Centrum voor de Bewaring van Historisch-Documentaire Collecties), bevindt zich een omvangrijk deel van de dossiers die tijdens het interbellum door het Parket van de Procureur des Konings te Brussel aangelegd werden ${ }^{(1)}$. Het vermoeden dat het hier gaat over slechts een deel van die dossiers lijkt gegrond als men merkt dat het merendeel bestaat uit rapporten uit de periode 1920-1923; over de periode erna zijn er veel minder inlichtingen.

Een officieuze inlichtingendienst was sinds december 1918 actief binnen het ministerie van Binnenlandse Zaken. De bestemmelingen van deze informatie waren de Eerste Minister en het Paleis. Op dat moment maakten socialistische ministers - onder andere Vandervelde als minister van Justitie - deel uit van de drieledige regeringen Delacroix en Carton de Wiart(1918-1921). Deze rapporten werden dan ook op de ministerraad besproken ${ }^{(2)}$. In het hierna beschreven archief vindt men de stukken van deze officieuze inlichtingendienst niet terug, dit archief is afkomstig van het Parket. In de loop van februari 1920 werd immers ook het Parket ingeschakeld; het zijn de briefwisseling van de Procureur des Konings te Brussel, de rapporten van de gerechtelijke politie en in mindere mate van de rijkswacht die het hoofdbestanddeel van de hier beschreven dossiers vormen.
De eerste rapporten zijn nogal onderhevig aan de fantasmen van de inlichtingsagenten - men lijkt op zoek naar een communistisch complot, men verdenkt de communisten ervan bomaanslagen te plegen - maar worden snel veel preciezer : de inlichtingsagenten hebben oog voor de meningsverschillen tussen de verschillende componenten die de KPB zullen vormen en ook de relaties met andere communistische (bv. de Clarté-groepen), anti-militaristische (vooral de Socialistische Oudstrijders), humanitaire (hulpcomités tegen de honger in de SovjetUnie) en anarchistische groeperingen worden gevolgd. Al is het duidelijk dat de agenten de werking van deze groeperingen minder goed begrijpen en dat de analyse vaak zwak is, dan zal men toch een schat aan informatie kunnen putten uit de dossiers. De inlichtingsagenten documenteerden zich omstandig en verzamelden veel feitelijke gegevens: namen van koeriers, schuilnamen, namen van sprekers, van correpondenten, affiches van meetings, krantenknipsels,... Dit alles, gevoegd bij de soms zeer accurate verslagen van communistische congressen en bijeenkomsten, moet ons in staat stellen een globaler en gedetailleerder beeld te krijgen van de ontstaansgeschiedenis van de KPB. Vooral als men uit de aard van de inlichtingen kan opmaken dat er op die bijeenkomsten soms 'mollen' zaten van de gerechtelijke politie. Die indruk krijgt men althans bij het lezen van bijvoorbeeld het verslag over het fusiecongres van september 1921 tussen enerzijds de groep rond De Kommunistische Arbeider/L'Ouvrier Communiste van War Van Overstraeten en anderzijds de groep Les Amis de l'Exploité van Joseph Jacquemotte. Men heeft ook weet van de reizen van de kopstukken van de partij, van de banden met Parijs, Amsterdam en Keulen, evenals van het bestaan van een coördinatiecentrum in Berlijn. Bovendien zijn er de zeer gedetailleerde rapporten over de huiszoekingen bij militanten. 
Op de arbeiders zelf schijnt de oppositie in de oude partij zich te steunen, die in de Brusselsche federatie der POB heel sterk is en die een orgaan heeft in "L'Exploité". De aanhangers van deze richting noemen zich "Les Amis de 1'Exploité" en hebben in tal van Waalsche streken groepen die dus in de POB zitten. Leiders:Jacquemotte, Massart, Everling. Op het congres der POB in december 1920 zijn deze uit de POB getreden, thans zijn ze aan het onder-handelen met Huysmans en consoorten of ze toch weer in de partij kunnen blijven. Erg halfslachtige lui, type recht en onafhankelijk. "L'Exploitê" coquetteert echter soms wel heel erg met de Bolsjewiki en Sowjet-Rusland. "L'Ouvrier Com-muniste" critiseert "L'Exploité" scherp en naar mijn mening volkomen terecht, al kan een buitenstaander als ik altijd vragen of de Communisten beter niet hadden gedaan voorloopig wat meer contact met deze elementen te zoeken.

Fragment uit bet dossier van de Procureur des Konings
Daar komt nog bij dat de briefwisseling van communisten soms onderschept werd. Verschillende gegevens uit deze rapporten kunnen aanleiding zijn voor verder studiewerk: wat te denken van de bewering dat Jacquemotte begin 1921 met Huysmans onderhandelde over de herintrede van zijn Exploité-groep in de BWP na de uitsluiting tijdens het congres van december 1920 ?

Het grote complot

Veruit het grootste deel van deze dossiers houdt verband met het proces tegen de KPB-leiding in 1923. Op het eerste gezicht is het onduidelijk waarom juist dan een proces plaatsvond: de fameuze staking van Ougrée-Marihaye (1921) was al een hele tijd achter de rug en de KPB was ondertussen niet opzienbarend sterker geworden of leek niet direct een grotere be- dreiging voor het politieke bestel te vormen dan een jaar ervoor. Enkele gebeurtenissen hebben waarschijnlijk meegespeeld. Ten eerste werd eind 1921 een regering samengesteld zonder socialisten en dus zonder Vandervelde op Justitie; meteen viel een rem weg om de communisten hard aan te pakken. Bovendien waren er twee onmiddellijke aanleidingen voor het oppakken op 8 maart 1923 van de vierenvijftig militanten van de jonge partij. Enerzijds was het weer rustig geworden in de Borinage na een staking van de mijnwerkers, en anderzijds bezetten Franse en Belgische troepen sinds 11 januari de Ruhr om herstelbetalingen van Duitsland te verkrijgen. Voor de KPB was dat een belangrijk werkingsveld om de internationale solidariteit in praktijk te brengen, voor rechtse kringen was het een kans om een beroep te doen op de patriottische gevoelens van de bevolking en zo de KPB in discrediet te brengen. De West-Europese communistische partijen 
hadden reeds in januari 1923 afspraken gemaakt over een gemeenschappelijke campagne tegen de bezetting en militarisering van de Ruhr; en ook in onze buurlanden reageerde de regering met repressie. Zo werd de PCF-leider Marcel Cachin opgesloten.

In België ging de arrestatie van de vierenvijftig militanten gepaard met huiszoekingen. De militanten werden beschuldigd van een complot tegen de staatsveiligheid (op basis van de artikels 104, 109 en 110 van het Strafwetboek). $\mathrm{Na}$ een eerste verhoor werden achttien beschuldigden opgesloten in de gevangenis van Vorst, al de anderen werden in voorlopige vrijheid gesteld ${ }^{(3)}$.

Het onderzoek vorderde maar traag - zo duurde het zes weken voor het parket Julien Lahaut vrijliet omdat hij op dat moment geen lid was van de KPB. Pas op 9 juni besliste de Kamer van Inbeschuldigingstelling om vijftien van de achttien militanten door te verwijzen naar het Assissenhof van Brabant. Het proces begon op 8 juli en eindigde op 26 juli met een volledige vrijspraak, omdat men op geen enkele moment een complot kon bewijzen.

In de omvangrijke bundels van dit rechtsdossier vindt men naast de vele procedurestukken, de verslagen van de ondervragingen, van de resultaten van de huiszoekingen bij de beschuldigden en andere militanten, administatieve inlichtingsfiches en individuele rapporten van de gerechtelijke politie, verslagen van rogatoire commissies, een rapport van een expertboekhouder, processen-verbaal van de debatten voor het Assisenhof..

Naast dit omvangrijk geheel zijn er ook nog enkele rapporten over de periode tussen 1924 en 1937; meestal handelen ze over de communistische jeugdorganisatie, anarchistische groepen en over de evoluties in het milieu van de Russische, Roemeense, Italiaanse... emigrés.

In totaal gaat het over bijna 7000 opnames; in Moskou kunnen de originelen op eenvoudige aanvraag door iedereen vrij geconsulteerd worden. Onderzoekers kunnen nu ook in het AMSAB terecht voor consultatie van een microfilm van dit interessant onderzoeksmateriaal. Uit onze briefwisseling met het Parket van de huidige Procureur des Konings te Brussel is er inzake de terbeschikkingstelling van de reproducties van dit archief geen bezwaar, uiteraard mits inachtneming van de gebruikelijke deontologische spelregels (bescherming van de persoonlijke levenssfeer...).

(1) J. GOTOVITCH, La peur du rouge dans les dossiers de la justice beige. In: P. DEIWIT en J. GOTOVITCH, La peur du rouge, Brussel: ULB, 1996, pp. 87-97.

(2) G. DENECKERE, Het "rode gevaar" tijdens het interbellum. In: Brood en Rozen, (1997)4, pp. 4965.

(3) LE PIC, Le grand "complot" communiste contre la Sureté de l'Etat, une machine de guerre de la bourgeoisie, Brussel: Les éditions socialistes, 1923, 73 p. 